\title{
ANTIMICROBIAL EFFICACY OF SOLAR DISINFECTION OF SELECTED DRINKING WELL WATER IN BENIN CITY, NIGERIA
}

\author{
*11Adebiyi, K. S., ${ }^{2}$ Emoresele, E. and ${ }^{3}$ Ogbonnaya., M. J.
}

\author{
*I\&2Department of Microbiology, Faculty of Life Sciences, University of Benin, Benin City, Nigeria \\ ${ }^{3}$ Department of Microbiology, Faculty of Sciences, Alex Ekwueme Federal University, Abakaliki, Nigeria \\ *Corresponding Author E-mail: adebiyisalem@gmail.com Phone: +2348138084808
}

\begin{abstract}
Solar Disinfection (SODIS) has been identified as a relatively cheap method of purifying water against pathogens, therefore providing potable drinking water, an essential component upon which living systems and the human body depends. In this study, the antimicrobial efficacy of solar disinfection of selected drinking well water was studied. A total of thirty (30) wells were randomly sampled from six (6) local government areas in Benin City, based on accessibility and communal usage. The well water was sampled using transparent 1L polyethene terephthalate (PET) bottles. Standard microbiological and biochemical test procedures were carried out to enumerate, isolate, characterize and identify the isolates to genus level. Antibiotic susceptibility of the isolates was also ascertained. Coliform tests were conducted and cell counts were expressed in Most Probable Number (MPN). The study revealed that Staphylococcus sp., Micrococcus sp., and Klebsiella sp. and, Penicillium sp., Fusarium sp. and Candida sp. were the most prevalent heterotrophic bacteria and fungi isolates in the study area in addition to faecal indicators (Escherichia coli and Fecal streptococci) with $83.33 \%$ occurrences respectively. The study also revealed that the overall percentage elimination of the identified isolates was recorded as $42.11 \%$, while the percentage elimination of faecal indicators identified was 50\%. It was observed that SODIS was very efficacious with a percentage reduction of above $95 \%$ for all identified isolates. It was also observed that SODIS is slightly more bactericidal as compared to its being fungicidal. From the study, it could not be ascertained with certainty whether or not, exposure to SODIS alters a microbial pathogens' antibiotic susceptibility. The use of SODIS did not completely eliminate all the faecal coliforms isolated in the studied well water, therefore making it unfit for drinking with regards to WHO recommendation. Consequently, the study recommends the use of SODIS only in conjunction with other water purification methods to ensure potability.
\end{abstract}

Keywords: Antimicrobial, Benin City, Bottles, Coliforms, Disinfection, Efficacy, Fecal, Pathogens, PET, SODIS, Solar, Water, Well

LICENSE: This work by Open Journals Nigeria is licensed and published under the Creative Commons Attribution License 4.0 International License, which permits unrestricted use, distribution, and reproduction in any medium, provided this article is duly cited.

COPYRIGHT: The Author(s) completely retain the copyright of this published article.

OPEN ACCESS: The Author(s) approves that this article remains permanently online in the open access (OA) mode.

QA: This Article is published in line with "COPE (Committee on Publication Ethics) and PIE (Publication Integrity \& Ethics)". 


\section{INTRODUCTION}

Water is an essential component upon which living systems and the human body depends. Moreover, the quality and potability of water is of immense importance for the optimal functioning of the human body. The WHO recommends that drinking water from any source including wells must be free from microbial pathogens for it to be considered safe for consumption. Due to pollution of drinking water with common sources of contaminants, potable water has become a rare commodity and of public health concern (Kuruf et al., 2010). A quick review of literature reveals that most sources of drinking water in Nigeria are polluted with both solid and liquid contaminants. Microbial pathogens especially coliforms are frequently isolated from various water sources including well water which exceeds WHO recommendation (Obafemi et al., 2018).

However, well water serves as a very cheap source of community water supply in most African and Asian countries. Well water is classified as groundwater and as such, the type and level of contamination in these water sources largely depends on the edaphic, topographic and anthropological characterization of the location which influences and contribute to the quality of the water (Palamuleni and Akoth, 2015).

Anthropogenic activities have been largely implicated with the pollution of most water bodies. Human activities such as the indiscriminate disposal of inorganic and microbial matter on the land surface or through direct injection of pollutants into water bodies (Sur et al., 2006). In addition, groundwater sources such as well water are largely contaminated by the practice of poor hygiene in most rural areas. Practices such as the indiscriminate use of contaminated fetching barrels or buckets to draw up water from deep wells, coughing, sneezing and chatting while fetching water have been identified as potential sources of well water contamination (Obafemi et al., 2018). Such contaminated well water adversely impacts the health and wellbeing of people who ingests them without proper treatment (Obire et al., 2008).

Various forms of treatment are employed all around the world to improve the potability of drinking water. At the community and household level, common water treatment methods such as; boiling, use of alum, decolouration, chlorination and filtration abounds. In Nigeria, boiling is the commonest method employed in household water treatment because it is relatively fast, efficient and comparatively cost-effective. However, with the current increase in the cost of burning fuel, most people are now seeking more cost-effective ways of treating domestic water. One of such low-cost alternatives is the use of solar radiation.

Solar Disinfection (SODIS) has been identified as a relatively cheap method of purifying water against pathogens (Burch and Thomas, 1998). This water treatment method is a very simple process involving the use of the sun's radiation to hamper the growth and destroy pathogenic microorganisms present in water. The use of the sun's radiation, which is universally available for all to use, is a free gift of nature. Being free of charge is the basis of its being a low-cost and sustainable form of water treatment (Odeyemi et al., 1988). Disinfection of water using the sun's rays has been carried out historically since Egyptian times. The London-based scientists, Downes and Blunt in the late 1870s were the first to build an experimental setup to study the process which was reported in scientific literature thereafter for the first time (Byrne et al., 2011). Solar Disinfection is also known as SODIS is best used for treating small quantities of drinking water with an un-universally agreed recommendation of two (2) litres per person per day 
and for small family use; approximately 10-15 litres per family per day (Wegelin et al., 1994). The process of solar disinfection of water is a relatively simple, cheap, efficient, useful, renewable and environmentally friendly process.

The process employs the combination of the sun's heating potential and its ultraviolet (UV) radiation to sufficiently inactivate and destroy pathogenic microorganisms present in a water sample (Burgess, 2002). Consequently, this study was conducted to evaluate the antimicrobial efficacy of solar disinfection of selected drinking well water in Benin City, Nigeria.

\section{MATERIALS AND METHODS}

\section{STUDY AREA}

This study was conducted in Benin City located in the south-south geopolitical zone of Nigeria. Benin City is bounded by latitudes $06^{\circ} 06^{\prime} \mathrm{N}, 06^{\circ} 30^{\prime} \mathrm{N}$ and longitudes $05^{\circ} 30^{\prime} \mathrm{E}, 005^{\circ} 45^{\prime} \mathrm{E}$ and the capital of Edo State. Benin City falls within the tropical equatorial zone dominated by dry season (November - March) and wet seasons (April - October). The average maximum and minimum temperatures are $34^{\circ} \mathrm{C}$ and $17^{\circ} \mathrm{C}$ in February and December respectively, with an average annual variation of $4^{\circ} \mathrm{C}$. The city is underlain by sedimentary formation. Its groundwater aquifer for wells ranges from $28.4 \mathrm{~m} 3 \mathrm{hr}-1$ at Iyanomo (south), $125 \mathrm{~m} 3 \mathrm{hr}-1$ at Uselu (central) to $208 \mathrm{~m} 3 \mathrm{hr}-1$ at Ogba (northern) with a drawdown ranging from $4.8 \mathrm{~m}$ at Iyanomo, $1.8 \mathrm{~m}$ at Uselu to $6.7 \mathrm{~m}$ at Ogba (Short and Stauble, 1967). Samples were collected from the six (6) local government areas within the city viz; Egor, Uhunmwonde, Ikpoba-Okha, Oredo, Ovia South-West and Ovia North-East. All samples were qualitatively researched at the Microbiology Departmental Laboratory, University of Benin, Benin City. (Adebiyi et al., 2020).

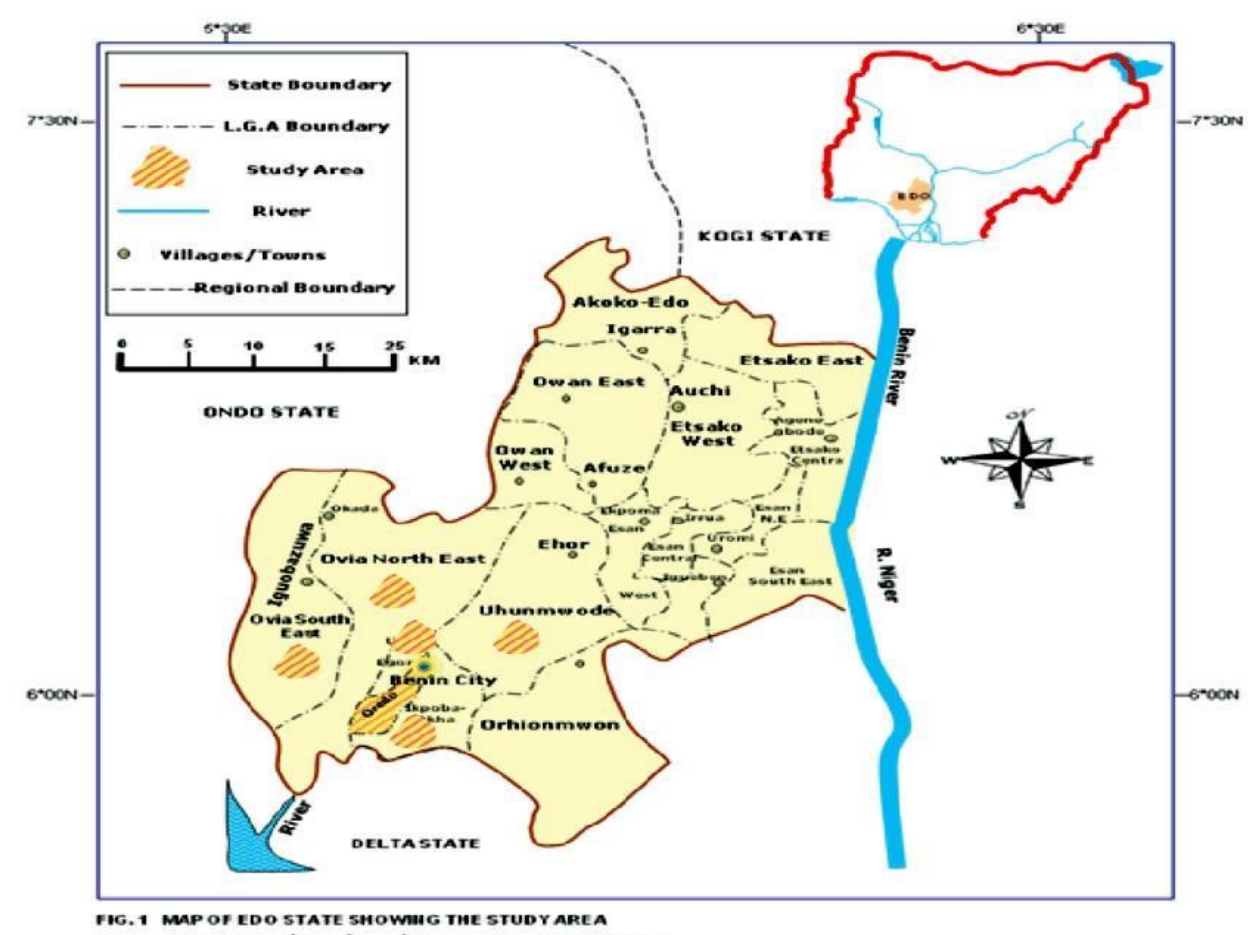

Figure 1: Map of Edo State showing the case study area. Source: Ministry of Lands and Survey, Benin City 2009 


\section{SAMPLE COLLECTION}

A total of thirty (30) wells were randomly sampled from the six (6) local government areas (LGAs), based on accessibility and communal usage, with five (5) samples from each. Thirty (30) transparent 1L polyethylene terephthalate (PET) bottles were purchased from a local dealer, washed with hypo bleach, soaked overnight in Brine, rinsed with distilled water and stored in sterile polyethylene bags for later use. Well water samples were collected using the prepared PET bottles tied with a strong string to a piece of pre-sterilized metal weighing 500g. The bottle cap was aseptically removed and the weighted bottle lowered into the well to a depth of about 1-2 meters. The bottle was brought up to the surface and covered with a screw cap when no air bubbles were seen inside (Aboh et al., 2015). The collected samples were immediately labelled, wrapped with a black polyethylene bag to prevent photocatalytic reactions and placed in ice-packed containers and sent to the laboratory for analysis.

\section{LABORATORY ANALYSIS}

The collected samples were taken to the laboratory for analysis with emphasis on the bacteriological quality of the water samples. Standard microbiological and biochemical test procedures were performed to enumerate, isolate, characterize and identify the isolates to genus level (Cheesbrough, 2000; 2002). Antibiotic susceptibility of the isolate to common antibiotics using Kirby-Bauer disc diffusion method was also carried-out. (Bauer et al., 1996) The coliform test was conducted using MacConkey broth in Durhams tubes while employing the Multiple Tube Fermentation technique/ (MPN - Most Probable Number). The technique used for water analysis was the MPN (American Public Health Association 1998) (Feng et al., 2014). Using the McCrady's probability tables, the MPN of coliforms in the $100 \mathrm{ml}$ well water sample was estimated (Mercy et al., 1998). These procedures were performed before (pre) and after (post) exposure to SODIS.

\section{PROCEDURE FOR SOLAR DISINFECTION (SODIS)}

Using the Google Weather Forecast App, a very sunny day for the study was picked with a forecasted clear sky, high temperature, low humidity and very low chance of precipitation. A total of thirty (30) transparent PET bottles was employed, of which, five (5) contained well water samples from each LGA. Of these; the content of two (2) bottles were used as "control" following the processes described above. The remaining three (3) bottles were used for SODIS procedure. Of these three (3) bottles, two (2) bottles were designated "Test-bottles" and the last one designated "Temp bottle". The contents of the Test-bottles were used for SODIS laboratory analysis, while the Temp bottles were used to determine the temperature of the exposed water during SODIS with the help of a thermometer. Test samples were drawn from the test bottles before and after exposure to SODIS. During the period of exposure, the solar radiance intensity (Average Peak Radiation Intensity (W/m2)) was measured using radiation sensors. During SODIS, the bottles were placed on the roof of the laboratory (made of old, rusted, brown-coloured aluminium roofing sheets) from $8 \mathrm{am} 4 \mathrm{pm}$ (8hrs) on the day of the study. Evaluation of the antimicrobial efficacy of solar disinfection (SODIS) of the sampled drinking well water was ascertained by assessing variation in the MPN value, re-occurrence of identified isolates and the isolates antibiotic susceptibility before (pre) and after (post) exposure to solar disinfection (SODIS). 


\section{STATISTICAL ANALYSIS}

Various statistical analysis was carried out to analyses the resulting data using Statistical package SPSS Version 22.0 and Microsoft Excel version 2015. Results are expressed in percentages, frequencies and graphical representation. (Ogbeibu, et al., 2015).

\section{RESULTS AND DISCUSSION}

\section{TEMPERATURE AND AVERAGE PEAK RADIATION INTENSITY}

Table 1 shows the mean temperature and average peak radiation intensity on SODIS bottles on the study day. The highest temperature reading was observed at midday with a mean value of $56 \mathrm{oC}$. The average peak radiation intensity recorded was $653.0 \mathrm{~W} / \mathrm{m} 2$.

Table 1: Mean Temperature and Average Peak Radiation Intensity on SODIS bottles

\begin{tabular}{cc}
\hline Mean Temperature $\left({ }^{\circ} \mathbf{C}\right)$ & $\begin{array}{c}\text { Average Peak Radiation Intensity } \\
\left(\mathbf{W} / \mathbf{m}^{2}\right)\end{array}$ \\
\hline 56.0 & 653.0 \\
\hline
\end{tabular}

\section{MICROBIAL ISOLATES DISTRIBUTION}

Table 2 shows the distribution of microbial isolates from the sampled well water in the six LGAs of Edo State. It was observed that among the isolated heterotrophic bacteria, Staphylococcus sp., Micrococcus sp., and Klebsiella sp. were the most prevalent in addition to the global faecal indicators (Escherichia coli and Fecal streptococci) with 83.33\% prevalence. Similar results were also observed by Ogueri et al., 2020, who conducted similar research on the "Bacteriological Quality of Borehole and Sachet Water from a Community in Southeastern Nigeria". Among the fungi isolates, Penicillium sp., Fusarium sp. and Candida sp. were most prevalent with $83.33 \%$ frequency of occurrence. It was also observed that Egor LGA had the highest prevalence of the isolates with a frequency of $78.95 \%$. A similar result was reported by Erah et al., (2002) who studied the "The Quality of Groundwater in Benin City: A baseline study on inorganic chemicals and microbial contaminants of health importance in boreholes and open wells". In this study, the researchers observed that Okhoro District in Benin City had very high levels of microbial contamination in their open wells. Coincidently, this district is within the Egor LGA. One possible reason for this high microbial prevalence may be due to the relatively shallower nature of the wells in this LGA. It was observed that only IkpobaOkha (Fecal streptococci) and Ovia South-West (Escherichia coli) LGAs had only one faecal indicator each as opposed to all other LGAs that had both. The high number of heterotrophic bacterial counts observed in the study area indicates that the groundwater in that area may be densely contaminated (Nwankwo et al., 2019). 
Table 2: Distribution of microbial isolates from sampled well water in six LGAs of Benin City, Nigeria

\section{Local Government Area}

$\begin{array}{llclll}\text { Isolates } & \text { Egor } & \text { Uhunmwonde Ikpoba-Okha Oredo } & \begin{array}{l}\text { Ovia } \\ \text { SouthWest }\end{array} & \begin{array}{l}\text { Ovia North-East } \\ \text { Nof isolates } \\ (\%)\end{array}\end{array}$

\section{Bacteria}

Staphylococcus sp.

Clostridium sp.

Salmonella sp.

Micrococcus sp.

Serratia sp.

Bacillus sp.

Shigella sp.

Klebsiella sp.

Proteus sp.

Citrobacter sp.

$\begin{array}{lll}+ & - & + \\ - & + & + \\ + & + & + \\ + & + & + \\ + & + & + \\ + & - & - \\ - & + & + \\ + & + & - \\ - & + & +\end{array}$

$\begin{array}{ll}+ & + \\ + & - \\ + & - \\ - & + \\ - & + \\ - & + \\ + & - \\ + & - \\ + & - \\ - & +\end{array}$

$+\quad 83.33$

$+\quad 66.67$

+
$-\quad 50.00$

$+\quad 83.33$

+
$-\quad 66.67$

$+\quad 66.67$

+
$-\quad 33.33$

$+\quad 83.33$

- $\quad 33.33$

50.00

Fecal Indicators

Escherichia coli

Fecal streptococci

$\begin{array}{ll}+ & + \\ + & +\end{array}$

$\begin{array}{ll}- & + \\ + & +\end{array}$

83.33

83.33

\section{Fungi}

Aspergillus sp.

Penicillium $s p$.

Rhizopus sp.

Fusarium sp.

Trichoderma sp.

Cladosporium sp.

Candida sp.

Frequency per LGA

(\%)

\begin{tabular}{ccccccc}
+ & + & - & + & + & - & 66.67 \\
+ & + & + & + & + & - & 83.33 \\
+ & - & + & + & - & + & 66.67 \\
+ & + & + & - & + & + & 83.33 \\
- & + & + & - & + & - & 50.00 \\
+ & - & - & + & - & + & 50.00 \\
+ & + & - & + & + & + & 83.33 \\
78.95 & 73.68 & 63.16 & 68.42 & 57.90 & 57.90 & $X^{2}=5.0000$ \\
& & & & & & $p=0.9989^{*}$ \\
\hline
\end{tabular}

$\mathrm{X}^{2}=$ Chi square; $*=$ not significant; LGA=Local Government Area

\section{OCCURRENCE OF ISOLATE BEFORE AND AFTER SODIS}

Table 3 shows the occurrence of identified microbial isolates before and after SODIS. It was observed that among the identified heterotrophic bacteria, Clostridium sp., Salmonella sp., Shigella sp., Proteus sp. and Citrobacter sp. were un-detectable after exposure to SODIS. The faecal indicator (Fecal streptococci) was also un-detectable. Among the identified fungi isolates, only Rhizopus sp. and Candida sp. became un-detectable. This goes to show that SODIS was more efficacious against bacteria as compared to fungi isolates. This might be attributed to the presence of spore and other vegetative forms of fungi which helps build resistance to radiations and adverse environmental conditions (Shuryak, 2019). The overall percentage elimination of the isolates identified in this study was recorded as $42.11 \%$. While the percentage elimination of faecal indicators identified was $50 \%$. 
Table 3: Occurrence of microbial isolates before and after SODIS

\begin{tabular}{|c|c|c|}
\hline Isolates & Before & After \\
\hline \multicolumn{3}{|l|}{ Bacteria } \\
\hline Staphylococcus sp. & + & + \\
\hline Clostridium sp. & + & - \\
\hline Salmonella sp. & + & - \\
\hline Micrococcus sp. & + & + \\
\hline Serratia sp. & + & + \\
\hline Bacillus sp. & + & + \\
\hline Shigella sp. & + & - \\
\hline Klebsiella sp. & + & + \\
\hline Proteus sp. & + & - \\
\hline Citrobacter sp. & + & - \\
\hline \multicolumn{3}{|l|}{ Fecal Indicators } \\
\hline Escherichia coli & + & + \\
\hline Fecal streptococci & + & - \\
\hline \multicolumn{3}{|l|}{ Fungi } \\
\hline Aspergillus sp. & + & + \\
\hline Penicillium sp. & + & + \\
\hline Rhizopus sp. & + & - \\
\hline Fusarium sp. & + & + \\
\hline Trichoderma sp. & + & + \\
\hline Cladosporium sp. & + & + \\
\hline Candida sp. & + & - \\
\hline \% Elimination of Isolates & & 42.11 \\
\hline
\end{tabular}

\section{MICROBIAL POPULATION OF THE WATER SAMPLES}

Table 4 shows the Most Probable Number (MPN) count of the isolates per 100 $\mathrm{ml}$ of the sampled water. It was similarly observed that Egor LGA had the highest count for all isolates. Again, this might be attributed to the relatively shallower nature of the wells in this LGA. This assertion is corroborated by Rajasekaran and Abinaya (2014) who posited that anthropogenic sources, such as seepages from domestic sewages and livestock wastes can also affect the quality of shallow groundwater sources in many parts of the world.

Table 4: Microbial population of the water samples across six LGAs of Benin City, Nigeria

\begin{tabular}{llll}
\hline \multicolumn{2}{c}{ Isolates } \\
\hline LGAs & $\begin{array}{l}\text { MPN count for bacteria } \\
\text { (per 100 ml) }\end{array}$ & $\begin{array}{l}\text { MPN count for fungi } \\
\text { (per 100 ml) }\end{array}$ & $\begin{array}{l}\text { MPN count for } \\
\text { coliforms (per 100 ml) }\end{array}$ \\
\hline Egor & 402 & 220 & 18 \\
Uhunmwonde & 346 & 184 & 7 \\
Ikpoba-Okha & 303 & 202 & 13 \\
Oredo & 268 & 106 & 15 \\
Ovia South-West & 188 & 87 & 9 \\
Ovia North-East & 132 & 103 & 12 \\
\hline
\end{tabular}

MPN $=$ Most Probable Number 


\section{MICROBIAL POPULATION BEFORE AND AFTER EXPOSURE TO SODIS}

Table 5 shows the Most Probable Number (MPN) count of the isolates per 100ml before and after exposure to SODIS. It was observed that SODIS was very efficacious with a percentage reduction of above $95 \%$ for all identified isolates. It was also observed that SODIS is slightly more bactericidal as compared to its being fungicidal. However, it was observed in this study that SODIS did not completely eliminate coliforms as it recorded $97.30 \%$ reduction. As a result, the disinfection process did not meet the WHO standard of zero (0) coliforms per drinking water sample. A similar result was observed by Ojo et al. (2011) who reported that coliforms in his study area (Ibadan, a relatively close by state to Edo State) were high in all the examined wells with values above the WHO standard.

Table 5: Microbial population before and after exposure to SODIS

\begin{tabular}{llll}
\hline Isolates & \multicolumn{2}{c}{ Exposure to SODIS } & \\
(MPN) & Before & After & \% Reduction \\
\hline Bacteria & 1639 & 36 & 97.80 \\
Fungi & 902 & 29 & 96.78 \\
Coliform & 74 & 2 & 97.30 \\
\hline
\end{tabular}

\section{ANTIBIOTIC SUSCEPTIBILITY PATTERN OF ISOLATES BEFORE AND AFTER SODIS}

Figure 2 shows the antibiotic susceptibility pattern of the isolates before and after SODIS. The figure shows that Staphylococcus sp. and Escherichia coli exhibited low antibiotic susceptibility before and after exposure to SODIS. Thus, SODIS did not alter the antibiotic susceptibility pattern of these isolates. However, Micrococcus sp., Serratia sp., Bacillus sp. and Citrobacter sp. showed a remarkable increase in antibiotic susceptibility after exposure to SODIS. However, this result could not be attributed with certainty to the effect of SODIS since this result was not observed for all the isolates tested.

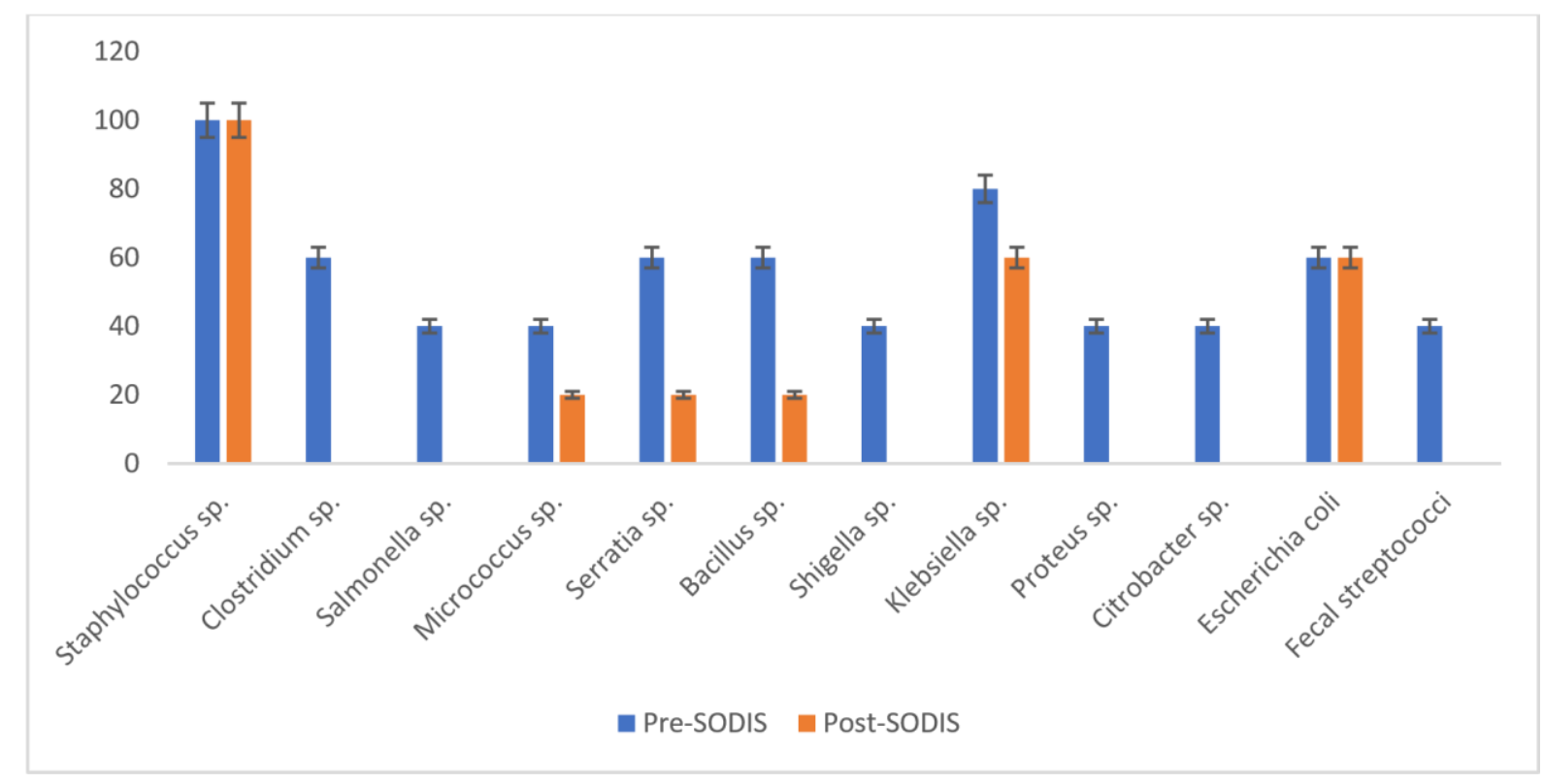

Figure 2: Percentage antibiotic susceptibility pattern of isolates before and after SODIS 


\section{CONCLUSION}

Water is an essential component upon which living systems and the human body depends. Moreover, the quality and potability of water is of immense importance for the optimal functioning of the human body. Well water serves as a cheap source of community water supply. The WHO recommends that drinking water from any source including wells must be free from microbial pathogens for it to be considered safe for consumption. Solar Disinfection (SODIS) has been identified as a relatively cheap method of purifying water against pathogens. In this study, the antimicrobial efficacy of solar disinfection of selected drinking well water was studied. The study revealed a plethora of microbial contamination of the well water in the study area including faecal coliforms. The use of SODIS had a moderate elimination efficacy on the identified isolates, though with a very high percentage reduction in the isolate count. From the study, it could not be ascertained with certainty whether or not, exposure to SODIS altered a microbial pathogens' antibiotic susceptibility. The use of SODIS did not completely eliminate all the faecal coliforms found in the studied well water, therefore making it unfit for drinking with regards to WHO recommendation. Consequently, the study recommends the use of SODIS only in conjunction with other water purification methods to ensure potability.

\section{ACKNOWLEDGMENT}

The authors acknowledge the financial support of Kivos Research Limited for part funding of this study.

\section{REFERENCES}

Aboh, E. A., Fatima, J. and Giwa, A. G. (2015). Microbiological assessment of well waters in Samaru, Zaria, Kaduna, State, Nigeria. Annals of African Medicine. 14(1)32-38. DOI: 10.4103/1596-3519.148732

Adebiyi, K. S., Emeka-Ifebi, A., Ogbonnaya., M. J. and Isiekwene, A. C (2020). Qualitative evaluation of the antimicrobial efficacy of UV sterilization chambers employed by barbershops in Benin City, Nigeria. African Journal of Clinical and Experimental Microbiology, 21(2)233-239. DOI: 10.4314/ajcem.v21i3.

Bauer, A. W., Kirby, W. M. M., Sherris, J. C. and Turck, M. (1996). Antibiotic susceptibility testing by a standardized single disk method. American Journal of Clinical Pathology. 45: 493-496.

Burgess, S. (2002). Solar Disinfection of Water: A Case Study from Kenya. ACK Christian Community Services, Kenya.

Burch, D. J. and Thomas, E. K. (1998). Water disinfection for developing countries and potential for solar thermal pasteurization. Solar Energy. 64(3)87-97

Byrne, A. J., Pilar, A. and Fernandez-Ibanez, Z. and Jeremy W. J. (2011). Photocatalytic Enhancement for Solar Disinfection of Water: A Review. International Journal of Photoenergy. 4(1)1-13. DOI: $10.1155 / 2011 / 798051$

Cheesbrough, M. (2000). Microbiological test: District Laboratory practice in Tropical Countries. Editors: Cremer. A. and Evan, G. Cambridge University Press, Cambridge, Great British, U.K. pp. 1-226.

Cheesbrough M (2002). District Laboratory Practice in Tropical Countries. Part 2: Cambridge University Press. Cambridge CBZ ZRU, UK. 2002; pp 64-68, 136-142.

Erah, O. P., Akujieze, N. C. and Oteze, E. G. (2002). The Quality of Groundwater in Benin City: A baseline study on inorganic chemicals and microbial contaminants of health importance in boreholes and open wells. Tropical Journal of Pharmaceutical Research, 1 (2): 75-82 
Feng, P., Weagent, S.D., Grant, M.A. and Burkhardt W. (2014). Enumeration of Escherichia coli and the coliform bacteria. Bacteriological Analytical Manual. Home Food Science and Research (Food) Laboratory Methods. Ch. 4, 2002. Revised February, 2013. Available from: http://www.fda.gov/food/food science Research/laboratory methods/uc. [Last accessed on 2021 Jan 18]

Kuruf, R. Persaud, R., Ceaser, J. and Raja, V. (2010) Microbiological and physiochemical analysis of drinking water George Town, Guyana. Nature and Science. 8(8):261-265

Rajasekaran R and Abinaya M. (2014). Heavy metal pollution in groundwater: A review. International Journal of Chemical Technological Research. 6(14):5661-5664

Macy, J. T. and Quick, R. G. (1998). Evaluation of a novel drinking water treatment and storage intention in Nicargagua. Revista Panamericanan de salud publica 3(1)135-136

Nwankwo, E. J., Agunwamba, C. J. and Nnaji, C. C. (2019). Effect of Radiation Intensity, Water Temperature and Support-Base Materials on the Inactivation Efficiency of Solar Water Disinfection (SODIS). Water Resources Management. 33(1)4539-4551. DOI: 10.1007/s11269-019-02407-4

Obafemi O., Olubanjo, O., Alade E., Adebolu, E., Olubanjo, M. and Abosede A. (2018). Bacteriological assessment of borehole and wells water in Akungba-Akoko, Nigeria. International Journal of Agriculture, Environment and Bioresearch. 3(6):2456-8643

Obire. O., Aguda, M. and Ramesh, R. P. (2018) Impact of human activities on drinking water quality. Journal of Basic and Applied Biology.2(3\&4):52-58

Odeyemi, O., Lawand, T., Alward, R., and Collett, R. (1988). Microbiological Aspects of Solar Water Disinfection. In Proceedings of a Workshop held at the brace Research Institute, Montreal, Quebec, Canada, pp.155 - 183

Ogueri N., Chiugo, C. A. and Oluyemisi E. O. (2020). Bacteriological Quality of Borehole and Sachet Water from a Community in Southeastern Nigeria. Pathogenic Bacteria, Sahra Kırmusaoğlu and Sonia Bhonchal Bhardwaj, IntechOpen, 31(1)4239-4251. DOI: 10.5772/intechopen.91812.

Ogbeibu, A.E. (2005). Biostatistics: A Practical Approach to Research and Data Handling 2nd edition. Mindex Publishing Company Lagos, Nigeria. 264pp.

Ojo, O. I., Ogedengbe, K. and Ochieng, M.G. (2011). Efficacy of solar water disinfection for well waters: Case study of Ibadan slums, Nigeria. International Journal of the Physical Sciences 6(5):1059-1067. DOI: $10.5897 /$ IJPS 10.428

Shuryak I. (2019). Review of microbial resistance to chronic ionizing radiation exposure under environmental conditions. Journal of environmental radioactivity, 196, 50-63. DOI: 10.1016/j.jenvrad.2018.10.012

Short, K. and Stauble, A. J. (1967). Outline of the geology of Niger Delta. American Association of Petroleum Geologists. Bull 51(1):761-790

Sur, D., Sarka, B. L., Dean, J., Delta, S., Niyogi, S. K. (2006). Epidemiological, microbiological and electron microscopic study of a cholera outbreak in a Kolkata slum community. Indian Journal of Medical Research 123:(1)31-36.

Palamuleni, L. and Akoth, M. (2015). Physico-chemical and microbial analysis of selected borehole water in Mahikeng, South Africa. International Journal of Environmental Research and Public Health. 12(1):86198630.

Wegelin, M., Canonica, S., Mechsner, K., Fleischmann, T., Pesaro, F. and Metzler, A. (1994). Solar Water Disinfection: Scope of the Process and Analysis of Radiation Experiments. Journal of Water. 43(3)154-196 